\author{
A.B. Salkynbai , U.U. Anarbekova \\ Al-Farabi Kazakh National University, Kazakhstan, Almaty, \\ e-mail: asalkbek@gmail.com; u.anarbekova@mail.ru

\section{AN ADEQUATE STATUS OF THE KAZAKH LANGUAGE AND ITS ACTUAL USE}

This article discusses the topical issue of the language that needs to be resolved today, the language of the Kazakh people, which has a long history existing since ancient times. We well know it that the name of the nation complies with the name of the language. And the reason for the name of the country Kazakhstan is that the founder and owner of this republic is the Kazakh nation. We will consider the status of the state language of an independent country of the Republic of Kazakhstan under the highest law of Kazakhstan, and the status of the Kazakh language in real life, the level of actual use. The information presented will be followed by reliable examples, we will acquaint readers with the proper status of the Kazakh language. This year marks the twenty-eight years to the independence of the Republic of Kazakhstan. To this day, the people of the country consider the Russian language as an official language of the state. This article discusses the reason the Russian language in the people's understanding is the official language, and how credible it is. We show the list of institutions where the Russian language has used on an equal level with the Kazakh language under the law on the language.

Key words: the Kazakh language, state language, official language, the usage of the Kazakh language, state status.

\author{
А.Б. Салқынбай, У.У. Анарбекова \\ Әл-Фараби атындағы Қазақ ұлттық университеті, Қазақстан, Алматы қ., \\ e-mail: asalkbek@gmail.com; u.anarbekova@mail.ru \\ Қазақ тілінің майықты мәртебесі және \\ оның іс жүзіндегі қолданысы
}

Бұл мақалада сан ғасырлық тарихы бар ежелгі заманнан бері келе жатқан қазақ халқының бүгінгі таңда өз шешімін табуға тиісті өзекті мәселелерінің бірі болып отырған тіл мәселесі талқыланады. Қай жерде болмасын ұлт атауы мен тіл атауы сәйкес келетіндігі бізге мәлім жағдай. А^, елдің Қазақстан деп аталу себебі бұл мемлекеттің негізін қалаушы әрі иесі қазақ ұлты болып табылатындығы. Ең ірі құрлықтың Азия бөлігінің жүрек тұсынан ойып тұрып орын алған егеменді мемлекет Қазақстан Республикасының мемлекеттік тілі болып табылатын қазақ, тілінің заң жүзіндегі және іс жүзіндегі мәртебесі жайлы сөз қозғалады. Берілген ақпарат дәйекті мысалдар арқылы нақтыланып, оқырман қауымға қазақ тілінің өзіне лайықты мәртебесі көрсетіледі. Үстіміздегі жылы Қазақстан Республикасы тәуелсіздік алғанына жиырма сегіз жыл болды. Осынша уақыт бойы егеменді Қазақ елі орыс тілін ресми тіл ретінде қабылдап келеді. Бұл мақалада орыс тілінің не себепті ресми тіл ретінде қолданылып жүргендігі айтылып, оның қаншалықты дұрыс екендігі талқыланады. Ата Заңымыз бен Тіл туралы Заңға сәйкес орыс тілінің қандай мекемелерде қазақ тілімен тең дәрежеде қолданылатындығы жайлы сөз қозғалып, ол орындар тізімі нақты көрсетімеді.

Түйін сөздер: қазақ тілі, мемлекеттік тіл, ресми тіл, қазақ тілінің қолданысы, мемлекеттік мәртебе.

\author{
А.Б. Салқынбай, У.У. Анарбекова \\ Казахский национальный университет им. аль-Фараби, Казахстан, г. Алматы, \\ e-mail: asalkbek@gmail.com; u.anarbekova@mail.ru \\ Аолжный статус казахского языка и \\ его фактическое использование
}

В этой статье рассматривается вопрос о языке казахского народа, который имеет многовековую историю, существует с Аревних времен, который является актуальной проблемой, требующей решения на сегодняшний день. Мы хорошо знаем, что название нации соответствует названию языка. И причина названия страны Казахстан в том, что основателем и владельцем 
этой республики является казахская нация. Казахская нация имеет свою историю. В этой работе мы рассмотрим статус государственного языка независимой страны Республики Казахстан в соответствии с высшим законом Казахстана, а также статус казахского языка в реальной жизни, уровень фактического использования. Представленная информация будет сопровождаться достоверными примерами, авторы знакомят читателей с наАлежащим статусом казахского языка. В этом году исполнилось Авадцать восемь лет со Аня независимости Республики Казахстан. Ао нынешних Аней народ страны принимал русский язык как официальный язык государства. В этой статье рассматривается причина, почему русский язык в понимании народа яв яется официальным языком, и насколько это правда. Указывается список учреждений, гАе русский язык используется наравне с казахским языком согласно закону о языке и конституции.

Кмючевые слова: казахский язык, государственный язык, официальный язык, использование казахского языка, государственный статус.

\section{Introduction}

The Kazakh language is the mother tongue of the Kazakh nation which compiles about $70 \%$ of all people of the Kazakhstan Republic, an independent country in the central Asia part of the Europe continent the biggest continent of the earth planet the only residence of all mankind. We well know it that the name of the nation complies with the name of the language. And the reason for the name of the country Kazakhstan is that the founder and owner of this republic is the Kazakh nation. The Kazakh nation has a long history. They are well-born courageous people whose early ancestors are Saka tribe who lived in the $1^{\text {st }}$ millennium $\mathrm{BC}$, after the Hun tribe and Usun tribe. Kazakh people founded their khanate (kingdom) in the middle of the XV century. One of the essential historical records about the establishment of the Kazakh khanate is "Tarikh-i-Rashidi (ىدىخرشىتـار) (History of Rashid)» written by historical writer Muhammad Haidar Dughlat who lived in Mugholstan. In this work, the author describes the foundation of the Kazakh khanate as: «Abulkhair khan ruled the Desht-i Qipchaq. He made miserable the life of the descendants of Zhoshy (Jochi) khan. As a result, Zhanibek and Kerei had moved to Mugholstan. Their khan Esenboga welcomed them with open arms and gave them the land from the west part of Mugholstan, the area of Shu and Qozybas.

After they settled down there, Abulkhair khan passed away and the situation in his khanate got worse. There were many serious fights. The majority of the citizens moved to Kerei and Zhanibek side. Therefore, the total amount of people had reached 200 thousand. Uzbeks called them «Kazakhs». Kazakh sultans started ruling in 870 years (14651466)...» (e-history.kz).

Kazakh khanate had existed in history for about four centuries, had had its ruling law, writing system, and literature, a vast land, wise, discreet, strong and valiant khans. It was a great khanate that kept and left today's territory of the Republic of Kazakhstan to its progeny.

In the XVIII century, Kazakh people had faced various severe conditions, for that reason they made a contract with the Russian empire to be at their disposal. In the beginning, they expected the relationship between the two countries to be as brothers' caring relationship, however, it ended up Kazakh people becoming a colony. When the Russian empire became a government, and the government became a union, the Kazakh people lived under the influence of Russian rule.

\section{Experiment}

Kazakh people were under Russia for about 300 years gained their independence in 1991 when Union of Soviet Socialist Republics (USSR) dissociated and the Republic of Kazakhstan had been acknowledged throughout the world. After declaring its independence, The Kazakh Republic had passed a law that has the highest powerful impact on every area of the country - The Constitution of the Republic of Kazakhstan.

It's known from the history that Kazakh people had their constitution before they became independent. They are the constitution of The Kazakh Autonomous Socialist Soviet Republic in 1926, The Kazakh Socialist Soviet Republic in 1937 and 1978. However, in these years Kazakhstan wasn't an independent country that's why people's rights were not protected completely.

They passed the first constitution of a sovereign Kazakhstan in 1993 on January 28, on IX session of the Supreme Council of Kazakhstan. It comprises an introduction, 4 parts, 21 chapters, and 131 articles. The constitution covered many legal norms such as,

- national sovereign

- independence of the country

- the principle of sharing power

- recognition of the Kazakh language as a state language 
- recognition of the President as Head of State

- Judicial authorities - Supreme, Constitutional and Higher Arbitration Courts, etc. The Constitution of 1993 was based on the parliamentary republic model (e-history.kz).

In 1989 the Language Law was adopted and the Kazakh language was given a state language status. They approved it in the 1993 Constitution.

They adopted the current Constitution of independent Kazakhstan on August 30, 1995. The Constitution comprises 9 chapters and 98 articles. They devote the 7 th article of the Constitution to language problem:

«Article 7

1. The state language of the Republic of Kazakhstan shall be the Kazakh language.

2. The Russian language shall be officially used on equal grounds along with the Kazakh language in state institutions and local self-administrative bodies.

3. The state shall promote conditions for the study and development of the languages of the people of Kazakhstan» (akorda.kz).

The information accurate in this article is that the Kazakh language is the state language. And now we can get the full answer on the question of what the state language is and how should we use it in Article 4 of the Language Law of the Republic of Kazakhstan N 151, adopted on July 11, 1997, based on this Constitution:

«Article 4. State language of the Republic of $\mathrm{Ka}$ zakhstan

State language of the Republic of Kazakhstan shall be the Kazakh language.

State language shall be the language of public administration, legislation, judicial and administrative procedure, acting in all fields of public relations on the territory of the state.

The duty of every citizen of the Republic of Kazakhstan shall be the mastery of the state language that shall be the most important factor in the people' consolidation of Kazakhstan.

The government and other governmental, local representative and executive bodies shall be obliged to:

fully develop the state language in the Republic of Kazakhstan, strengthen its international authority;

create all necessary organizational material and technical conditions for unrestricted and free mastery of the state language by all citizens of the Republic of Kazakhstan;

assist to Kazakh diaspora in the preservation and development of their native language» (adilet.zan.kz).

Thus, by the Language Law, our state language the Kazakh language should be used in all regions of our country in every field as the language of usage and language of documentation management. As it's shown in the third sentence of this article, a state language is the most important factor in the people' consolidation of Kazakhstan. For that reason, each citizen of The Kazakhstan Republic has to master the state language - the Kazakh language. A duty is a responsibility of the human being to fulfil the obligations concerning the people and society. Mastering the state language is an obligation of not only representatives of the Kazakh nation but also representatives of over 140 ethnic groups living in Kazakhstan. We should note it that this article of the Language Law is appropriate. The Kazakh people are the most populous among the peoples living in our country there are also many ethnic groups. To live in peace, all members of each nationality living in Kazakhstan should know the state language which is an important factor for joining the people of this land. Most other nations who inhabit our country are the descendants of Turkic people: Kyrgyz, Uzbek, Tatar, Uyghur, Turkish, Tajik, etc. People of these nations can learn the state language of Kazakhstan with no difficulties since the languages of these nations and the Kazakh language are relative languages. For people who speak Slavic languages such as Russian and Ukraine languages, mastering the state language is not a difficult task either. Many representatives of these nations fluent in the Kazakh language can be proof of that. Talking about many other nationalities who speak the Kazakh language can be written as a separate article with credible examples. If we look at the next following sentences of this article, we see the ways of bringing into action the requirements given in the previous sentences.

According to the Law to use the state language in every area of Kazakhstan by all the nations living in the government and other governmental, local representative and executive bodies shall be obliged to develop the state language in the Republic of Kazakhstan, strengthen international, authority of the Kazakh language, create all necessary organizational, material and technical conditions for unrestricted and free mastery of the state language by all citizens of the Republic of Kazakhstan and assist to Kazakh diaspora in preservation and development of their native language. Therefore, under the Constitution of the Republic of Kazakhstan, and the Language Law, if all the tasks were fulfilled properly the status of the Kazakh language would be much higher than the status we know today. Speaking more precisely, since the Kazakh language is a state language, citizens of the Republic of Kazakhstan, regardless of the origin of their nationality, would speak the same language as the common language and use 
the Kazakh language; In all institutions, they would conduct the proceedings in the state language; they would recognize the Kazakh language at a certain level in an international arena; Kazakh diasporas abroad would be well-acquainted with Kazakh as their native language. 22 years could achieve that result. Here, the natural question arises. Why does not the Kazakh language have its proper status in real life as the status of under the Constitution? Why does the Russian language share this status, and most cases used in the Kazakh language's place? The reason is paragraph 2 of Article 7 of the Constitution of the Republic of Kazakhstan. Some analysis will reveal the correctness of the answer.

Article 7 of the Constitution of the Republic of Kazakhstan:

\section{«Article 7}

2. The Russian language shall be officially used on equal grounds along with the Kazakh language in state institutions and local self-administrative bodies» (akorda.kz).

Article 5 of the Language Law of the Republic of Kazakhstan:

\section{«Article 5. The use of The Russian language}

In governmental organizations and local government on a level with the Kazakh language officially shall be used the Russian language» (adilet. zan.kz).

We know from the previously described articles that we should use the state language in every field as a language of documentation management. By this article, we can use the Russian language on the same level as the state language in two types of organizations such as governmental organizations and local government. We need to understand that here it doesn't say about using the Russian language in all spheres rather only in two kinds of organizations. In all other places the state language, approved by the Constitution, should be in use. One more important aspect that we should pay attention is there is no such content as «the Russian language is an official language of the Republic of Kazakhstan», that means they do not give the Russian language status of official language. Therefore, to make it clear in what places we can use the Russian language on the same level as the state language, we will list the places that are considered as governmental organizations and local government.

The following is a list of organizations in the category of government organizations:

- The Administration of the President of Kazakhstan;

- The Assembly of People of Kazakhstan;

- Damu (Development found);

- Kazairnavigation;
- Administrative Office of the Prime Minister of the Republic of Kazakhstan;

- The State Accumulative Pension Fund;

- The National Bank of Kazakhstan;

- Stocks of trust assets (ru.wikipedia.org).

The following is a list of organizations in the subcategory of government organizations:

- Institutions of the Republic of Kazakhstan:

o Agencies of the Republic of Kazakhstan:

-The Agency for Economic and Corruption

Crimes of the Republic of Kazakhstan;

- The National Anti-Corruption Bureau;

- The Agency for State Service Affairs of the Republic of Kazakhstan;

- The National Space Agency of the Republic of Kazakhstan;

- The Agency for Regulation of Natural Monopolies in the Republic of Kazakhstan;

- The Agency for Religious Affairs of the Republic of Kazakhstan;

- The statisticscommittee of MNE RK;

- The Agency for Construction, Housing and Utilities of the Republic of Kazakhstan;

- The Agency for Regulation and Supervision of Financial Market and Financial Organizations of the Republic of Kazakhstan;

o Committees of the Republic of Kazakhstan:

- Kazakhstan National Security Committee;

o Ministries of the Republic of Kazakhstan:

- The Ministry of Foreign Affairs of the Republic of Kazakhstan;

- The Ministry of Internal Affairs of the Republic of Kazakhstan;

- The Ministry of Defense of the Republic of Kazakhstan;

- The Ministry of Information and Social Development of the Republic of Kazakhstan;

- The Ministry of Agriculture of the Republic of Kazakhstan;

- The Ministry of Justice of the Republic of Kazakhstan;

-The Ministry of Education and Science of the Republic of Kazakhstan;

- The Ministry of Healthcare of the Republic of Kazakhstan;

- The Ministry of Labor and Social Protection of Population of the Republic of Kazakhstan;

- The Ministry of Industry and Infrastructural

Development of the Republic of Kazakhstan;

- The Ministry of Finance of the Republic of Kazakhstan;

- The Ministry of Culture and Sports of the Republic of Kazakhstan;

- The Ministry of National Economy of the Republic of Kazakhstan; 
- The Ministry of Digital Development, Innovations and Aerospace Industries of the Republic of Kazakhstan;

- The Ministry of Energy of the Republic of Kazakhstan;

- The Ministry of Trade and Integration of the Republic of Kazakhstan;

- The Ministry of Ecology, Geology and Natural Resources of the Republic of Kazakhstan (egov.kz).

o State companies of Kazakhstan:

- Zerde;

- Kazakhstancaspishelf;

- United Chemical Company;

- KEGOC.

o Special services in Kazakhstan:

- Kokzhal (special division);

- SYRBAR;

- The State Security Service of the Republic of Kazakhstan

- Sunqar

o The National Security Committee of the Republic of Kazakhstan (ru.wikipedia.org).

We consider organizations listed as governmental organizations. For that reason, these places use the Russian language on the same level as the Kazakh language by Constitution and Law of Language.

«Bodies of local self-government-bodies, on which under this Law imposed functions by the decision of issues of local significance» (adilet.zan. $\mathrm{kz}$ ). We've taken this definition from The Law of the Republic of Kazakhstan dated 23 January 2001, No 148 on Local Government and Self-government in the Republic of Kazakhstan. Therefore, the number of local self-government bodies includes rural, rural district, city, district, regional akimats and maslikhats.

\section{Results and discussion}

In all the above local self-administrative bodies, the Russian language is used equally with the Kazakh language. This has approved by the constitution and the Law of Language. And in all institutions, except for these places, there are no grounds for using the Russian language equally with the state language. Both the Constitution and the Language Law do not support this.

So, it turned out that our previous response to the questions «Why does not the Kazakh language have its proper status in real life as the status of under the Constitution? Why does the Russian language share this status, and most cases used in the Kazakh language's place? » as «the reason is, paragraph 2 of
Article 7 of the Constitution of the Republic of Kazakhstan» is not correct. The Constitution does not give the Russian language the status of «official language» in this article; plus, they limit places, where we can use the Russian language equally use with the state language. The conclusion is that the constitution is not followed accordingly and not properly explained to the people. Any citizen who reads this second paragraph understands that the Russian language does not have the status of «official language».

However, media representatives are so enthusiastic that the Russian language is "official language», so we do not go to enrich and accept the information we read. It is difficult to say what the reason for the mass media representatives to give the Russian language official language status. Media representatives should always know the strong power they possess in connecting the government and the people and they need to keep in mind that it does not entitle them to make such a gross mistake in interpreting state documents. One of the main reasons for the failure of the Kazakh language to win a worthy status is that the people who use the Russian language «protect» themselves by claiming that the Russian language is understood as the «official language» of the Republic of Kazakhstan. Because our journalists explained it to them in that way. We give the following example to prove our statement. Reporter of the national TV channel Qazaqstan in their reportage named «we have found Hotels that have not complied with the Law on Language in Atyrau» (youtu.be) stated, «in many places they write information for the guests and menu in the official language». By official language, they mean the Russian language. It's easy to list such examples. However, we would like to ask the media who has a huge power not to confuse people by misinterpreting the information.

In conclusion, our goal is not to say people should forget the Russian language or to be ignorant of this language rather say the Kazakh language should own its worthy status. If we mastered the native language well, it would not be wrong to know another language. As Alash movement figure, doctor, teacher, scientist Khalel Dosmukhameduly said: «If you speak another language well knowing your mother tongue, then it's pleasant. If you speak another language well not knowing your mother tongue, then it's sorrow. Imitating other languages without knowing your native language is a big mistake» (Salkynbay, 2016: 45). Unfortunately, most of our people speak in another language well than their native language. 


\section{Conclusion}

It's time for the brave Kazakh people, who have overcome many obstacles in their deep history to cherish, master in the highest level, give its worth status of the magnificent gift from the Almighty the Kazakh language. For that, we need definitely to follow the Law, and there are some suggestions to remove completely the Russian language from the Constitution. We support this idea. Notwithstanding, every citizen of Kazakhstan has to understand and accept the notion «my state language is the Kazakh language, and mastering this language is my duty» instead of understanding the Russian language as an official language of the Republic of Kazakhstan. We don't mean to make people learn the language by forcing rather by showing them how beautiful and rich this language is and this should be our goal. The Constitution must protect the language. The great Kazakh hero Bauyrzhan Momyshuly described the Kazakh language: «The Kazakh language-the beautiful language that melts the body, temper the veins, burns whole your soul system, delights the ear, motivates the man and the people by its sharpness in hard times, it's a mature language that can break off not only the person but the situation itself» (massaget.kz). We consider it as a natural law that such wonderful language lives in this world till the end, and it's a lifelong duty for people whose hearts beat for Kazakhs to serve on this path.

There is a saying of khan Ablai from the XVIIInth century: «From the Tian-Shan Mountains to the AralSea lies a land that has been inhabited by the Kazakhs since ancient times. The vast land from the Irtysh to the Volga, from Sarırqato the Alatau Mountains, is the motherland of the Kazakhs. All who dare to encroach upon this land will be beaten and driven out as has been done with the Jungers. We will greet our friends with open arms, but to our enemies, we will show no mercy» (kerekinfo.kz). We would like to conclude by saying that every citizen of the homeland of the Kazakhs should be eager to learn and master the state language accordingly to its proper status by the Constitution.

\section{Литература}

https://e-history.kz/kz/contents/view/507

http://e-history.kz/kz/publications/view/723

http://www.akorda.kz/en/official_documents/constitution/The Republic of Kazakhstan, Nur-Sultan, «Akorda» Presidential Residence.

http://adilet.zan.kz/eng/docs/Z970000151_/C 2012. «Institute of legislation and legal information of the Republic of Kazakhstan» of the Ministry of Justice of the Republic of Kazakhstan.

ru.wikipedia.org/wiki/Категория: Государственные организации Казахстана

https://egov.kz/cms/kk/information/state_agencies/ministries_committees/ C Қазақстан Республикасының Электрондық үкіметі.

http://adilet.zan.kz/eng/docs/Z010000148_(C 2012. РГП на ПХВ «Институт законодательства и правовой информации

Республики Казахстан» Министерства юстиции Республики Казахстан.

https://youtu.be/IriDriw4OPs/Aqparat / Ақпарат

Салқынбай А. Қазақ тіл білімі тарихы: оқу құралы - Алматы: Қазақ университеті, 2016. - 220 б.

https://massaget.kz/layfstayl/debiet/bauyirjan_momyishulyi/31992/C Massaget.kz, 2011-2020.

http://kerekinfo.kz/2011/09/02/abylay-han-1.html / Көшпенділер, 2005.

\section{References}

https://e-history.kz/kz/contents/view/507 (In Kazakh)

http://e-history.kz/kz/publications/view/723 (In Kazakh)

http://www.akorda.kz/en/official_documents/constitution, The Republic of Kazakhstan, Nur-Sultan, "Akorda" Presidential

Residence (In English)

http://adilet.zan.kz/eng/docs/Z970000151_C 2012. «Institute of legislation and legal information of the Republic of Kazakhstan» of the Ministry of Justice of the Republic of Kazakhstan (In English)

ru.wikipedia.org/wiki/Категория: Государственные_организации_Казахстана

https://egov.kz/cms/kk/information/state_agencies/ministries_committees/ C Electronic government of the Republic of Kazakhstan (in Kazakh)

http://adilet.zan.kz/eng/docs/Z010000148_ (C) 2012. РГП на ПХВ «Институт законодательства и правовой информации

Республики Казахстан» Министерства юстиции Республики Казахстан

https://youtu.be/IriDriw4OPs/Aqparat / Ақпарат (In Kazakh)

https://massaget.kz/layfstayl/debiet/bauyirjan_momyishulyi/31992/C Massaget.kz, 2011-2020 (in Kazakh)

http://kerekinfo.kz/2011/09/02/abylay-han-1.html / Koshpendiler, 2005 (In Kazakh)

Salkynbay A. Kazakh til biliminin taryhy: oku kuraly. Almaty: Kazakh universiteti, 2016. 220 b. (In Kazakh) 